\title{
Synthesis of Tricyclic Nucleoside Analogue of $O^{6}$-Methyl-2'-Deoxyguanosine
}

\author{
Kabir Abdu and David M. Williams
}

\begin{abstract}
Alkylation at the O6-position of guanine leads to one of the most significant mutagenic lesions in DNA, $O^{6}$-alkylguanine. The human protein $O^{6}$-methylguanine-DNA methyltransferase (MGMT) repairs these lesions by transferring the alkyl group to an active site cysteine in an irreversible manner. The levels of MGMT are often higher in tumour cells which reduce the effectiveness of many chemotherapeutic agents that alkylate DNA. This has led to the development of inactivators of this protein for use in chemotherapy. To learn more about the repair mechanism carried out by MGMT, a high resolution MGMT-DNA structure is required which may enable the design of new inhibitors to improve current cancer treatments.

Here we discribed the synthesis of 4-amino-2-(2'-deoxy- $\beta$-D-erythro-pentofuranosyl)-6-oxa-7,8, 9-trihydro-2,3,5-triazabenzo $[c d]$ azulene (2), a tricyclic nucleoside analogue of $O^{6}$-methyl-2'-deoxyguanosine
\end{abstract}

Index Terms-Alkylation, cancer, guanine, inactivation.

\section{INTRODUCTION}

Alkylation at the $O^{6}$-position of guanine leads to one of the most significant mutagenic lesions in DNA; $O^{6}$-alkylguanine which has many biological effects. The mutagenicity of this analogue (causes GC to AT transition mutations) as well as cytotoxicity is well documented and its DNA repair is undertaken by $O^{6}$-methylguanine-DNA methyltransferase (MGMT) protein [1]-[3]. The repair mechanism involves an $\mathrm{S}_{\mathrm{N}} 2$ process in which the alkyl group is transferred to $\mathrm{SH}$ group of the cysteine residue which renders the protein inactive with the regeneration of guanine[4]. Although MGMT performs an important task in the repair of the $O^{6}$-alkylguanine lesions in DNA, it also promotes tumour resistance to certain alkylating agents commonly used in cancer treatment. MGMT is thus of great interest in the field of cancer chemotherapy and treatment because since the most common method used in cancer therapy is DNA alkyalation which works by damaging DNA and induction of cancer cells apoptosis. Since MGMT repairs alkylation damage, its expression therefore counteracts these forms of treatment [5]. Also its high level of expression in certain types of tumour cells negates the therapeutic benefit of the cancer chemotherapy from the alkylated products [6]. Recently ATL proteins (alkyltransferase-like proteins) were discovered which are homologues of alkyltransferases that bind to, but do not de-alkylate DNA containing $O^{6}$-alkylguanine lesions.

Manuscript received January 8, 2013; revised March 7, 2013.

Kabir Abdu is with Department of Pure and Industrial Chemistry Bayero university, Kano Nigeria (email: kbrabdu@yahoo.com).

David M. Williams is with Centre for Chemical Biology, Department of Chemistry, University of Sheffield, Sheffield S3 7HF, UK.
In most ATL proteins the active site cysteine is substituted by tryptophan [7].

Different approaches have been taken to target the MGMT in the development of anti-cancer therapy. The success of MGMT depletion depends upon the $O^{6}$-alkylation being the determinant of the cancer cell death. Several attempts to deplete the level of MGMT through the provision of larger doses of alkylating agents or combining multiple agents so that the number of $O^{6}$-alkylguanine adducts in DNA exceeds the number of MGMT molecules were unsuccessful due to the toxicity [8], [9]. This problem has led to the increasing interest in designing more effective inhibitors of MGMT and understanding the repair reaction process. We have been interested for some time in incorporating tricyclic analogues of $O^{6}$-methylguanine into DNA that may allow covalent cross-linking of such DNA to MGMT or Atl1 (via a suitable mutant). Such complexes will allow structural information to be derived via X-ray crystallography or would provide suitable protein-DNA complexes for identification of protein partners from crude cell lysates.

Prior to Daniels' crystal structure in 2004, all crystal structures of MGMT or related alkyltransferases from other organisms were obtained in the absence of substrate DNA [10]. In 2001, Noll and Clarke described the formation of an MGMT -DNA complex as a result of interstrand cross-links via $N^{1}, O^{6}$-ethanoguanine (1) Fig. 1 [7].
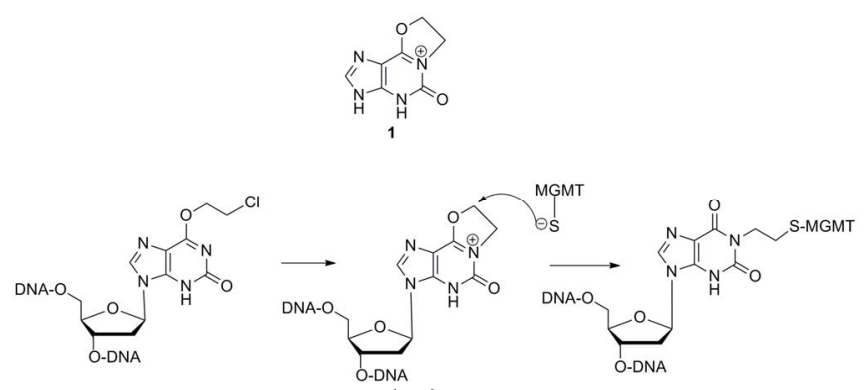

Fig. 1. Cross-linking reaction of $N^{1}, O^{6}$-ethanoguanine MGMT proposed by Noll and Clarke[11]

In this cross-linked crystal complex the cross-linking is between the N2-position of the base and the protein, in which case no interaction will be observed between the $\mathrm{NH}_{2}$ group and the protein since it is replace by the carbonyl group (Fig. 1). Our target compound 2 was designed to be cross-linked at C7-position which will allow clear observation for any possible interaction between the $\mathrm{NH}_{2}$ and the protein (Fig. 2).

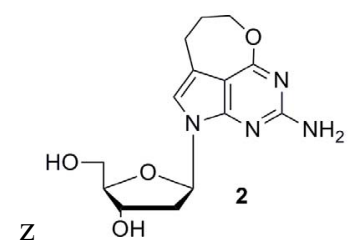




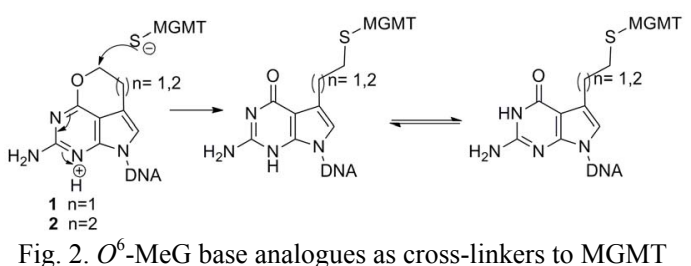

Here we describe chemistry directed to the synthesis of the nucleoside 2 .

\section{RESUlTS AND DISCUSSION}

The synthesis of the key intermediate pyrrolo [2, 3-d] pyrimidinone 9 was achieved in seven steps from butane-1, 4-diol (Fig. 3).

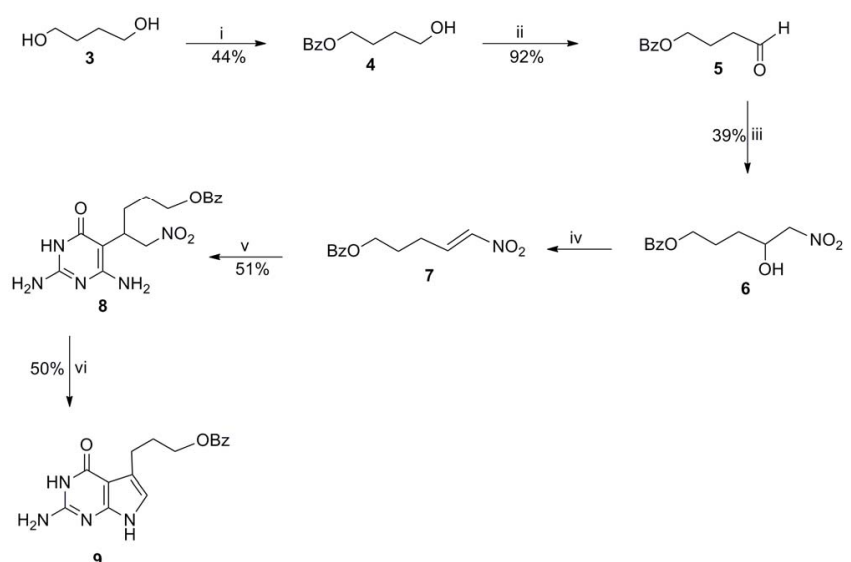

Fig. 3. Synthesis of 9 from butane-1,4-diol 3.

Reagents and conditions: (i) $\mathrm{C}_{5} \mathrm{H}_{5} \mathrm{~N}, \mathrm{Et}_{3} \mathrm{~N}$ then $\mathrm{BzCl}$; (ii) $\mathrm{PCC}, \mathrm{CH}_{2} \mathrm{Cl}_{2}$; (iii) $\mathrm{CH}_{3} \mathrm{NO}_{2}$, EtOH, $\mathrm{NaOH}$; (iv) $\mathrm{MsCl}, \mathrm{CH}_{2} \mathrm{Cl}_{2}$, then $\mathrm{Et}_{3} \mathrm{~N}, \mathrm{CH}_{2} \mathrm{Cl}_{2}$; (v)

2,6-diamino-4(3H)-pyrimidinone, EtOAc/ $\mathrm{H}_{2} \mathrm{O}$; (vi) $\mathrm{SnCl}_{2}, \mathrm{PhSH}_{2} \mathrm{Et}_{3} \mathrm{~N}$, $\mathrm{MeCN}, \mathrm{rt}, 3 \mathrm{~h}$.

Thus, butane-1, 4-diol 3 was monobenzoylated using benzoyl chloride in pyridine and triethylamine to give 4-benzoyloxy-1-butanol 4, in approximately $44 \%$ yield. The monobenzoylated product is formed together with a bis-benzoylated diol (40\%) and some of the starting material was found unreacted from the TLC of the reaction mixture. The crude product was distilled under reduced pressure and Compound 4 was isolated as colourless oil which solidifies as a white solid at room temperature.

The benzoylated alcohol 4 was oxidised using pyridinium chlorochromate (PCC) in dichloromethane to give a monobenzoylated aldehyde, 4-benzoyloxybutanal 5. Hyflo super cel and silica were added to the reaction mixture at the beginning in order to make the purification easier. The black residue of the PCC was removed through filtration using a column loaded with three layers of sand, hyflo super cel and silica. The column was eluted with dichloromethane and the filtrate was evaporated and the product 5 , was obtained as a colourless oil in $92 \%$ yield.

Compound 5 was converted into the nitro alcohol 6, by an aldol condensation with nitromethane. The crude product was obtained as an orange-yellow oil which solidified at room temperature. Silica column chromatography afforded the pure nitro alcohol 6 , in $39 \%$ yield.

The nitro alcohol was subjected to dehydration using methanesulfonyl chloride at $0^{\circ} \mathrm{C}$. The reaction involves forming a mesylate intermediate which allows E2 elimination following a slow addition of dry triethylamine. This led to the formation of an alkene, (E)-5-nitropent-4-enylbenzoate 7 which was used straight away in the next reaction without further purification due to its tendency to polymerise.

The Michael addition of the commercially available 2,6-diamino-4-pyrimidinone to nitro olefin 7 in a mixture of water and ethylacetate was performed at $50^{\circ} \mathrm{C}$ overnight. The desired Michael-coupled product was obtained as a yellow foam which was recrystallised from 1,4-dioxane.

The pyrrolopyrimidine 9 was obtained in a two-step, one pot reaction via an oxime intermediate. This chemistry is analogous to that previously described for the corresponding benzyl derivatives of compound 8 [12]. The pyrrolopyrimidine 9 was precipitated along with inorganic compounds after acidification, but was poorly soluble in most solvents which complicated its purification. Recrystallisation with $10 \%$ aqueous acetonitrile was for some batches acceptable, whilst silica column chromatography was run as the second alternative. Compound 9 eluted from the column with some gummy material which appered to be a triethylammonium salt according to ${ }^{1} \mathrm{H}$ NMR evidence. Compound 9 was obtained in 50\% yield using silica chromatography.

There are a number of different synthetic routes toward achieving the bis-chlorinated nucleobase 11 [13] but the most feasible one is given in Fig. 4.
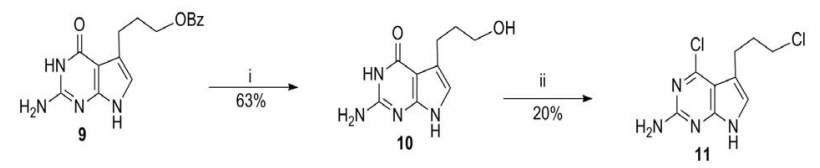

Fig. 4. Synthesis of bis-chlorinated nucleobase 11 Reagents and reaction conditions: (i) $\mathrm{NaOH}, 50^{\circ} \mathrm{C}$, $1 \mathrm{~h}$; (ii) $\mathrm{POCl}_{3}$, reflux at $80^{\circ} \mathrm{C}, 2 \mathrm{~h}$.

Debenzoylation was carried out by refluxing compound 9 in $1 \mathrm{M} \mathrm{NaOH}$ at $50^{\circ} \mathrm{C}$ for one hour. The mixture was neutralised with acetic acid and after column chromatography afforded the pure pyrrolopyrimidine alcohol 10 as white solid in $63 \%$ yield.

The bis-chlorination was carried out on compound 10 by refluxing with phosphoryl chloride at $80^{\circ} \mathrm{C}$ for two hours. The product was purified by silica column chromatography to give a white solid 11 in 20\% yield. Compound 9 was found to be insoluble in acetonitrile (usual solvent for glycosylation reaction). Furthermore, the presence of the lactam $\mathrm{NH}$ in addtion to the pyrrolic NH could leads to both N1and N4 glycosylated residue. Thus, the benzoyl protected pyrrolopyrimidine 9 was converted into dichloro compound 11. In addition, it was expected that bis-chlorinated nucleoside 13 might proceed intramolecular nucleophilic reaction (upon treatement with a base) which can leads to the cyclisation into the tricyclic nucleoside 2 .

Glycosylation of the bis-chlorinated nucleobase 11 was achieved by reaction of its sodium salt with 1-chloro-2-deoxy-3,5-di-O-p-toluoyl- $\alpha$-D-erythro-pentofura nose (chlorosugar) in anhydrous acetonitrile. ${ }^{13}$ Removal of the toluoyl protecting groups was achieved by treatment with a 1:1 mixture of $1 \mathrm{M}$ aq. $\mathrm{NaOH} / 1,4$-dioxane. TLC analysis showed that compound 14 was obtained after overnight 
stirring but after 3 days, two nucleosides, the tricyclic nucleoside 2 ( $R_{f} 0.45$ in $\left.10 \% \mathrm{MeOH} / \mathrm{DCM}\right)$ which is fluorescent under UV and the ring open nucleoside 15 were observed. Purification by silica column chromatography gave compound 2 in $19 \%$ yield and 15 in $42 \%$ yield (Fig. 5).
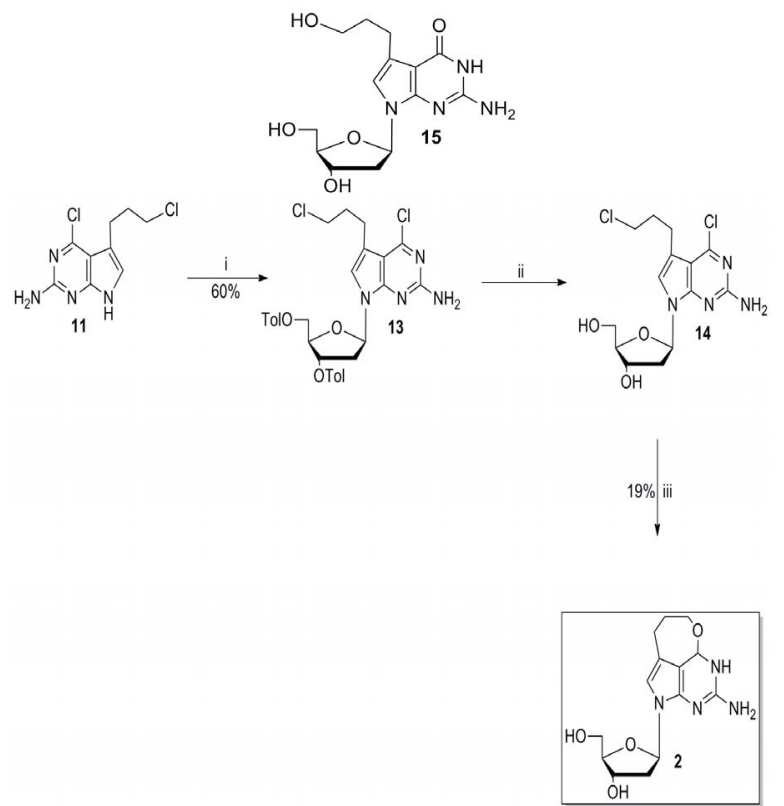

Fig. 5. Glycosylation of bis-chlorinated nucleobase and cyclisation to obtain nucleoside 14

Reagents and reaction conditions: (i) $\mathrm{NaH}, \mathrm{MeCN}$, then " $\alpha$-chlorosugar", rt, $3 \mathrm{~h}$; (ii) $1: 1$ mixture of $1 \mathrm{M}$ aq. $\mathrm{NaOH} / 1,4$-dioxane, $90^{\circ} \mathrm{C}$, overnight; (iii) $1: 1$ mixture of $1 \mathrm{M}$ aq. $\mathrm{NaOH} / 1,4$-dioxane, $90^{\circ} \mathrm{C}, 3$ days.

In conclusion, synthesis of compound 2 was successfully achieved via the bis-chlorinated intermediate 11 . We are currently engaged in incorporating the tricyclic nucleoside into DNA which will be subsequently reported elsewhere.

\section{EXPERIMENTAL}

Most of the solvents were obtained from Fisher and used without further purification if they were not requested to be anhydrous in the reaction procedure. Pyridine, acetonitrile and triethylamine were dried under reflux from calcium hydride and then distilled and stored over $3 \AA$ molecular sieves under $\mathrm{Ar}$. $\mathrm{MeOH}$ was dried under reflux from magnesium and iodine, then distilled and stored over $3 \AA$ molecular sieves under Ar. N,N-Dimethylformamide and tetrahydrofuran were obtained as an anhydrous solvent from Aldrich. Phosphoryl chloride was freshly distilled just before use. Silica TLC were; A (dichloromethane), B ( $2 \%$ methanol in dichloromethane), $\mathrm{C}$ (10\% methanol in dichloromethane) and D (20\% methanol in dichloromethane). The developed TLC plates were viewed under UV and stained with anisaldehyde. Nuclear Magnetic Resonance (NMR) spectra were run on a Bruker AC-250 spectrometer or AMX-400 spectrometer. ${ }^{1} \mathrm{H}$ spectra were run at $250.13 \mathrm{MHz}$ or 400.13 $\mathrm{MHz}$ and ${ }^{13} \mathrm{C}$ spectra at $62.83 \mathrm{MHz}$ or $100.61 \mathrm{MHz}$. All chemical shifts are quoted in ppm relative to tetramethylsilane as an external standard. All coupling counstants are quoted in Hertz. All mass spectra were obtained from the university of sheffield mass spectrometry service.

\section{A. 4-(Benzoyloxy)Butanol (4)}

A solution of 1,4-butanediol (20.00 g, $222.2 \mathrm{mmol}$.) was dissolved in pyridine (19.00 g, $242.3 \mathrm{mmol}$.) followed by the addition of dichloromethane $(33 \mathrm{~mL})$ and cooled to $0^{\circ} \mathrm{C}$ in an ice-bath. Benzoyl chloride (16.00 g, $12.8 \mathrm{~mL}, 110.0 \mathrm{mmol})$ in dichloromethane $(20 \mathrm{~mL})$ was added dropwise and the reaction was left to stir overnight. The solution was diluted with ether $(100 \mathrm{~mL})$ and the organic phase was washed with water $(3 \times 20 \mathrm{~mL})$, sodium bicarbonate solution $(3 \times 20 \mathrm{~mL})$, dried $\left(\mathrm{MgSO}_{4}\right)$ and evaporated. The resulting oil was purified by silica column chromatography (eluted with ethyl acetate: hexane $1: 1)$ to obtain a colourless oil $(22.10 \mathrm{~g}, 51 \%)$ : $\mathrm{R}_{\mathrm{f}}(\mathrm{A})$, $0.3 ; \delta_{\mathrm{H}}\left(\mathrm{CDCl}_{3}\right) 1.75\left(2 \mathrm{H}, \mathrm{m}, \mathrm{CH}_{2} \mathrm{CH}_{2} \mathrm{OH}\right), 1.85(2 \mathrm{H}, \mathrm{m}$, $\left.\mathrm{CH}_{2} \mathrm{CH}_{2} \mathrm{CH}_{2} \mathrm{OH}\right), 3.71\left(2 \mathrm{H}, \mathrm{t}, J 6.5, \mathrm{CH}_{2}-\mathrm{OBz}\right), 4.35(2 \mathrm{H}, \mathrm{t}, \mathrm{J}$ 6.5, $\left.\mathrm{CH}_{2} \mathrm{OC}=\mathrm{O}\right), 7.42-7.63\left(3 \mathrm{H}, \mathrm{m}, \mathrm{CH}_{2} \mathrm{Ph}-\right), 8.14(2 \mathrm{H}, \mathrm{d}, \mathrm{J}$ 7.3, $\mathrm{CH}, \mathrm{Ph}) ; \mathrm{m} / \mathrm{z}(\mathrm{ES}+) 217\left(\left[\mathrm{M}^{+}(\mathrm{Na})^{+}\right] 100 \%\right)$; Acc Mass: 217.0835; calculated for $\mathrm{C}_{11} \mathrm{H}_{14} \mathrm{O}_{3} \mathrm{Na}$ requires 217.0841 (deviation $-2.8 \mathrm{ppm}$ ).

\section{B. 4-(Benzoyloxy)Butanal (5)}

A solution of 4-benzoyloxybutanol (4) (14.75 g, 76.0 mmol.) in dichloromethane $(100 \mathrm{~mL})$ was added in one portion to a solution of a stirred suspension of pyridinium chlorochromate $98 \%$ (35.88g, $166.5 \mathrm{mmol}$.), hyflosuper cel $(10 \mathrm{~g})$ and silica (10 g), the pyridinium chlorochromate, hyflosuper cel and silica where well stirred in dichloromethane $(200 \mathrm{~mL})$ in an ice-bath before adding the alcohol. After addition the bright orange suspension becomes black. The reaction was left stirring for $3 \mathrm{~h}$. until complete (checked by silica TLC). The solution was separated from the black precipitate by filtration using a column containing three layers; sand, hyflosuper cel and silica. The column was eluted with dichloromethane and the filtrate was evaporated to give a colourless oil $(13.71 \mathrm{~g}, 93 \%) ; \mathrm{R}_{\mathrm{f}}(\mathrm{A}), 0.54 ; \delta_{\mathrm{H}}\left(\mathrm{CDCl}_{3}\right) 2.12$ $\left(2 \mathrm{H}, \mathrm{m}, \mathrm{CH}_{2} \mathrm{CH}_{2} \mathrm{CHO}\right), 2.60\left(2 \mathrm{H}, \mathrm{t}, J 6.5, \mathrm{CH}_{2} \mathrm{CHO}\right), 4.61$ (2H, J 6.5, $\mathrm{CH}_{2}$-OBz), 7.45-7.60 and 8.05 (5H, m, $\left.\underline{\mathrm{CH}}, \mathrm{Ph}-\right)$, $9.84(\mathrm{~s}, 1 \mathrm{H}, \mathrm{CHO}) ; \delta_{\mathrm{C}}\left(\mathrm{CDCl}_{3}\right) 20.4\left(\mathrm{CH}_{2} \mathrm{CH}_{2} \mathrm{CHO}\right), 39.5$ ( $\left.\mathrm{CH}_{2} \mathrm{CHO}\right), 62.9\left(\mathrm{CH}_{2}-\mathrm{OBz}\right), 126.0$ (1 para $\left.\mathrm{CH}-\mathrm{Ph}\right), 127.0$ (2 meta $\mathrm{CH}-\mathrm{Ph}), 128.0$ (2 ortho $\mathrm{CH}-\mathrm{Ph}), 132.0$ (C-Ph), 165.4 $(\mathrm{O}=C-\mathrm{Ph}), 200.1(\mathrm{CHO}) ; \mathrm{m} / \mathrm{z}(\mathrm{ES}+) 193\left([\mathrm{M}+\mathrm{H}]^{+}\right.$100\%).

\section{5-(Benzoyloxy)-1-Nitropentan-2-ol (6)}

4-Benzoyloxybutanal 5 (12.90 g, $67.2 \mathrm{mmol}$.) and nitromethane $(4.10 \mathrm{~g}, 67.2 \mathrm{mmol}$.) were dissolved in equal volume of ethanol (30 mL each) and cooled in an ice-bath to $0^{\circ} \mathrm{C}$ and sodium hydroxide $(6 \mathrm{M}, 2.8 \mathrm{~g}$ in $12 \mathrm{~mL}$ water) was added dropwise over $3 \mathrm{~h}$. so that the temperature did not exceed $0^{\circ} \mathrm{C}$. Ice water $(50 \mathrm{~mL})$ was then added to the reaction mixture followed by the addition of glacial acetic acid until the precipitated salt was dissolved and the $\mathrm{pH}$ was 6 . The solution was extracted with ethyl acetate $(175 \mathrm{~mL})$ and the organic phase was washed with water $(50 \mathrm{~mL})$, then saturated sodium chloride solution $(50 \mathrm{~mL})$, then dried $\left(\mathrm{MgSO}_{4}\right)$ and evaporated to give orange-yellow oil (11.70 g). Purification by silica column chromatography (eluted with dichloromethane) gave a pale-yellow oil which solidifies at room temp. (6.60 g, $26.2 \mathrm{mmol}, 39 \%) ; \mathrm{R}_{\mathrm{f}}(\mathrm{B}), 0.44 ; \delta_{\mathrm{H}}$ $\left(\mathrm{CDCl}_{3}\right) 1.60\left(2 \mathrm{H}, \mathrm{m}, \mathrm{CH}_{2} \mathrm{CH}_{2} \mathrm{OBz}\right), 1.94(2 \mathrm{H}, \mathrm{q}, J$ 6.2, $\left.\mathrm{CH}_{2} \mathrm{CH}_{2} \mathrm{CH}_{2} \mathrm{OBz}\right), \quad 4.45\left(3 \mathrm{H}, \quad \mathrm{m}, \quad \mathrm{CH}(\mathrm{OH}) \mathrm{CH}_{2} \mathrm{NO}_{2}\right.$, $\left.\mathrm{CH}_{2}-\mathrm{OBz},\right), 7.45-8.0(5 \mathrm{H}, \mathrm{m}, \mathrm{CH}-\mathrm{Ph}) ; \delta_{\mathrm{C}}\left(\mathrm{CDCl}_{3}\right) 24.8$ 
( $\left.\mathrm{CH}_{2} \mathrm{CH}_{2} \mathrm{CHOBz}\right), 30.7\left(\mathrm{CH}_{2} \mathrm{CH}_{2} \mathrm{CH}_{2} \mathrm{OBz}\right), 64.9\left(\mathrm{CH}_{2} \mathrm{-OBz}\right)$, $68.2(\mathrm{CH}-\mathrm{OH}), 82.0\left(\mathrm{CH}_{2} \mathrm{NO}_{2}\right), 129.2$ and $129.5(5 \mathrm{CH}-\mathrm{Ph})$, $133.7(C-\mathrm{Ph}), 166.2(\mathrm{O}=C-\mathrm{Ph}) ; \mathrm{m} / \mathrm{z}(\mathrm{ES}+) 276\left(\left[\mathrm{M}^{+}\left(\mathrm{Na}^{+}\right)\right]\right.$; Acc. Mass: 276.0853: calculated for $\mathrm{C}_{12} \mathrm{H}_{15} \mathrm{NO}_{5} \mathrm{Na}$ requires 276.0848 (deviation $1.7 \mathrm{ppm}$ ).

\section{D. (E)-5-Nitropent-4-Enylbenzoate (7)}

Methanesulfonyl chloride $(2.00 \mathrm{~g}, 17.7 \mathrm{mmol})$ was added to stirred solution of $6(4.50 \mathrm{~g}, 17.7 \mathrm{mmol})$ in dry dichloromethane $(30 \mathrm{~mL})$ at $0^{\circ} \mathrm{C}$ under an argon atmosphere. Dry triethylamine $(4.9 \mathrm{~mL}, 35.4 \mathrm{mmol})$ was then added via a syringe pump at the rate $5 \mathrm{~mL} \mathrm{~h}^{-1}$. When the reaction was completed, the mixture was transferred to a separating funnel with dichloromethane $(30 \mathrm{~mL})$ and the organic layer was sequentially washed with water $(20 \mathrm{~mL}), 5 \% \mathrm{HCl}(20 \mathrm{~mL})$, $10 \% \mathrm{Na}_{2} \mathrm{CO}_{3}(20 \mathrm{~mL})$ and brine $(20 \mathrm{~mL})$. The organic layer was dried $\left(\mathrm{MgSO}_{4}\right)$ and the solvent removed in vacuo, giving the crude product $7(2.60 \mathrm{~g}, 11.1 \mathrm{mmol}, 63 \%)$ as an orange oil, which was used further without further purification. $\mathrm{R}_{\mathrm{f}}(\mathrm{B})$ 0.44; $\delta_{\mathrm{H}}\left(\mathrm{CDCl}_{3}\right) 2.03\left(2 \mathrm{H}, \mathrm{m}, \mathrm{CH}_{2} \mathrm{CH}_{2} \mathrm{OBz}\right), 2.44(2 \mathrm{H}, \mathrm{q}, J$ 6.8, $\left.\mathrm{CH}_{2} \mathrm{CH}_{2} \mathrm{CH}_{2} \mathrm{OBz}\right), 4.40\left(2 \mathrm{H}, \mathrm{t}, \mathrm{J} \mathrm{6.8}, \mathrm{CH}_{2} \mathrm{-OBz}\right.$ ), 6.90 $\left(1 \mathrm{H}, \mathrm{t}, J 6.8, \mathrm{CHCHNO}_{2}\right), 7.31-8.09\left(6 \mathrm{H}, \mathrm{m}, 1 \mathrm{H} \mathrm{CHNO}{ }_{2}\right.$ and $\begin{array}{llllll}5 \mathrm{H} & \mathrm{CH}-\mathrm{Ph}) ; \quad \delta_{\mathrm{C}} & \left(\mathrm{CDCl}_{3}\right) & 25.3 & \left(\mathrm{CH}_{2} \mathrm{CH}_{2} \mathrm{OBz}\right), & 27.0\end{array}$ $\left(\mathrm{CH}_{2} \mathrm{CH}_{2} \mathrm{CH}_{2} \mathrm{OBz}\right), 63.6\left(\mathrm{CH}_{2}-\mathrm{OBz}\right), 128.4$ and 129.5 (5 $\mathrm{CH}-\mathrm{Ph}), 133.2(\mathrm{C}-\mathrm{Ph}), 140.0\left(\mathrm{CHCHNO}_{2}\right), 141.3\left(\mathrm{CHNO} \mathrm{NO}_{2}\right)$, $166.0(\mathrm{O}=C-\mathrm{Ph}) ; \mathrm{m} / \mathrm{z}(\mathrm{ES}+) 236[\mathrm{MH}]^{+}$.

\section{E. 2,6-Diamino-5-[5-Benzoyloxy-1-Nitropentan-2-yl]Pyri midin-4(3H)-One (8)}

A solution of 2,6-diamino-4(3H)-pyrimidinone $(5.40 \mathrm{~g}$, $42.6 \mathrm{mmol})$ in water $(60 \mathrm{~mL})$ and alkene $7(10.00 \mathrm{~g}, 42.6$ $\mathrm{mmol})$ in ethylacetate $(60 \mathrm{~mL})$ were mixed and stirred overnight at $65^{\circ} \mathrm{C}$. The organic layer was then washed with water $(60 \mathrm{~mL})$, dried $\left(\mathrm{MgSO}_{4}\right)$ and the solvent removed in vacuo to give a yellow foam. Purification by silica column chromatography $\left(10 \% \mathrm{MeOH}\right.$ in $\left.\mathrm{CH}_{2} \mathrm{Cl}_{2}\right)$ gave a light yellow foam $(7.80 \mathrm{~g}, 21.6 \mathrm{mmol}, 51 \%) ; \mathrm{R}_{\mathrm{f}}(\mathrm{C}), 0.40 ; \delta_{\mathrm{H}}\left(\mathrm{d}_{6}-\mathrm{DMSO}\right)$ 1.50-1.75 (4H, m, $\left.\mathrm{CH}_{2} \mathrm{CH}_{2} \mathrm{CH}_{2} \mathrm{OBz}\right), 1.98-2.06(1 \mathrm{H}, \mathrm{m}$, $\left.\mathrm{CHCH}_{2} \mathrm{NO}_{2}\right), 4.20\left(2 \mathrm{H}, \mathrm{s}, \mathrm{CH}_{2} \mathrm{OBz}\right), 4.73-4.79(1 \mathrm{H}, \mathrm{m}$, $\left.\mathrm{CH}_{2} \mathrm{NO}_{2}\right), 4.99\left(1 \mathrm{H}, \mathrm{dd}, J 6.2,11.6, \mathrm{CH}_{2} \mathrm{NO}_{2}\right), 6.00(2 \mathrm{H}, \mathrm{s}$, $\left.\mathrm{NH}_{2}\right), 6.10\left(2 \mathrm{H}, \mathrm{s}, \mathrm{NH}_{2}\right), 7.40-8.01(5 \mathrm{H}, \mathrm{m}, \mathrm{CH}-\mathrm{Ph}) 9.80(1 \mathrm{H}$, s, NH); $\quad \delta_{\mathrm{C}} \quad\left(\mathrm{d}_{6}\right.$-DMSO $) \quad 26.3 \quad\left(\mathrm{CH}_{2} \mathrm{CH}_{2} \mathrm{OBz}\right), \quad 26.6$ $\left(\mathrm{CH}_{2} \mathrm{CH}_{2} \mathrm{CH}_{2} \mathrm{OBz}\right), 55.3\left(\mathrm{CHCH}_{2} \mathrm{NO}_{2}\right), 65.1\left(\mathrm{CH}_{2} \mathrm{OBz}\right)$, $78.1\left(\mathrm{CH}_{2} \mathrm{NO}_{2}\right), 84.2(\mathrm{C}-5), 129.1$ and $129.5(5 \mathrm{CH}-\mathrm{Ph})$, 130.3 (C-2), 133.6 (C-Ph), $154.0(C-6), 166.1$ (2 $C=\mathrm{O}) ; \mathrm{m} / \mathrm{z}$ $(\mathrm{ESI}+) 362[\mathrm{M}+\mathrm{H}]^{+}$; Acc Mass: 384.1296; calculated for $\mathrm{C}_{16} \mathrm{H}_{19} \mathrm{~N}_{5} \mathrm{O}_{5} \mathrm{Na}$ requires 384.1284 (deviation $3.2 \mathrm{ppm}$ ).

\section{F. 2-Amino-5-(3-Benzoyloxypropyl)-3,7-Dihydropyrrolo[} 2,3-d]Pyrimidin-4-One (9)

Thiophenol (3.83 g, $35.2 \mathrm{mmol})$ and triethylamine (3.61 g, $35.2 \mathrm{mmol}$ ) were added to a solution of tin (II) chloride dihydrate $(2.22 \mathrm{~g}, 11.7 \mathrm{mmol})$ in $\mathrm{MeCN}(10 \mathrm{~mL})$ and water $(10 \mathrm{~mL})$. The reaction was stirred for $10 \mathrm{~min}$ at room temp, then a solution of compound $8(16.00 \mathrm{~g}, 44.3 \mathrm{mmol})$ in MeCN $(10 \mathrm{~mL})$ was added. The mixture was then stirred for $30 \mathrm{~min}$., then a solution of tin (II) chloride dihydrate (1.63 g, $8.6 \mathrm{mmol})$, L-tartaric acid $(5.90 \mathrm{~g}, 39.0 \mathrm{mmol})$ and sodium hydrogen carbonate $(4.58 \mathrm{~g}, 54.6 \mathrm{mmol})$ in water $(15 \mathrm{~mL})$ was added in one portion, followed by a solution of sodium hydrogen sulfite $(4.06 \mathrm{~g}, 39.0 \mathrm{mmol})$ in water $(10 \mathrm{~mL})$. The reaction mixture was then heated to $40^{\circ} \mathrm{C}$ for $3 \mathrm{~h}$, cooled to room temp, then poured into a $1: 1$ mixture of $2 \mathrm{M}$ aq $\mathrm{HCl}$ solution $(30 \mathrm{~mL})$ and ethyl acetate $(30 \mathrm{~mL})$ at $0^{\circ} \mathrm{C}$. The mixture was then neutralised with $10 \%$ aq ammonia solution then filtered and the ethyl acetate layer was then washed with water, dried $\left(\mathrm{Na}_{2} \mathrm{SO}_{4}\right)$ and evaporated. The residue was purified by silica column chromatography $(0-10 \%$ $\left.\mathrm{MeOH} / \mathrm{CH}_{2} \mathrm{Cl}_{2}\right)$ to give a white solid $(6.90 \mathrm{~g}, 50 \%) ; R_{\mathrm{f}}(\mathrm{C})$, $0.40 ; \delta_{\mathrm{H}}\left(d_{6}\right.$-DMSO) $2.02\left(2 \mathrm{H}, \mathrm{t}, J 7.3, \mathrm{CH}_{2} \mathrm{CH}_{2} \mathrm{OBz}\right), 2.70$ (2H, t $\left., J 7.3, \mathrm{CH}_{2} \mathrm{CH}_{2} \mathrm{CH}_{2} \mathrm{OBz}\right), 4.24\left(2 \mathrm{H}, \mathrm{t}, J 6.2, \mathrm{CH}_{2} \mathrm{OBz}\right.$ ), $5.97\left(2 \mathrm{H}, \mathrm{s}, \mathrm{NH}_{2}\right), 6.35(1 \mathrm{H}, \mathrm{s}, \mathrm{H}-6), 7.47-7.98(5 \mathrm{H}, \mathrm{m}$, $\mathrm{CH}-\mathrm{Ph}), 10.20(1 \mathrm{H}, \mathrm{s}, \mathrm{NH}-3), 10.75(1 \mathrm{H}, \mathrm{s}, \mathrm{NH}-7) ; \delta_{\mathrm{C}}$ (d $d_{6}$-DMSO) $23.0\left(\mathrm{CH}_{2} \mathrm{CH}_{2} \mathrm{OBz}\right), 29.4\left(\mathrm{CH}_{2} \mathrm{CH}_{2} \mathrm{CH}_{2} \mathrm{OBz}\right)$, $64.8\left(\mathrm{CH}_{2} \mathrm{OBz}\right), 113.9$ (C-5), 117.7 (C-4a), 127.1 (C-6), 127.7 (1 para $\mathrm{CH}-\mathrm{Ph}), 129.1$ (2 ortho $\mathrm{CH}-\mathrm{Ph}), 129.5$ (2 meta CH-Ph), 130.3 (C-7a), 133.6 (C-Ph), 151.8 (C-2), 152.6 $(C-4), 159.7(C=\mathrm{O}) ; \mathrm{m} / z(\mathrm{ESI}+) 313[\mathrm{M}+\mathrm{H}]^{+}$; Acc Mass: 335.1116; calculated for $\mathrm{C}_{16} \mathrm{H}_{16} \mathrm{~N}_{4} \mathrm{O}_{3} \mathrm{Na}$ requires 335.1120 (deviation -1.3 ppm).

\section{G. 2-Amino-5-(3-Hydroxypropyl)-3,7-Dihydropyrrolo[2, 3-d]Pyrimidin-4-One (10)}

Compound 9 (5.00 g, $15.9 \mathrm{mmol})$ was added to a solution of $\mathrm{NaOH}(2.00 \mathrm{~g}, 31.9 \mathrm{mmol})$ in water $(20 \mathrm{~mL})$ and reflux at $50^{\circ} \mathrm{C}$ for $3 \mathrm{hrs}$. The precipitated compound was filtered and washes on filter paper with water $(3.00 \mathrm{~g}, 63 \%) ; R_{\mathrm{f}}(\mathrm{C}), 0.40$; $\delta_{\mathrm{H}}\left(d_{6}\right.$-DMSO $) 1.65\left(2 \mathrm{H}, \mathrm{m}, \mathrm{CH}_{2} \mathrm{CH}_{2} \mathrm{OH}\right), 2.55(2 \mathrm{H}, \mathrm{t}, J 6.2$ $\left.\mathrm{Hz}, \mathrm{CH}_{2} \mathrm{CH}_{2} \mathrm{CH}_{2} \mathrm{OH}\right), 3.35\left(2 \mathrm{H}, \mathrm{t}, J 6.2, \mathrm{CH}_{2} \mathrm{OH}\right), 4.47(1 \mathrm{H}, \mathrm{s}$, OH) $5.97\left(2 \mathrm{H}, \mathrm{s}, \mathrm{NH}_{2}\right), 6.35(1 \mathrm{H}, \mathrm{s}, \mathrm{H}-6), 10.20(1 \mathrm{H}, \mathrm{s}, \mathrm{NH}-3)$, $10.75(1 \mathrm{H}, \mathrm{s}, \mathrm{NH}-7) ; \delta_{\mathrm{C}}\left(d_{6}\right.$-DMSO) $22.7\left(\mathrm{CH}_{2} \mathrm{CH}_{2} \mathrm{OH}\right), 34.0$ $\left(\mathrm{CH}_{2} \mathrm{CH}_{2} \mathrm{CH}_{2} \mathrm{OH}\right), 60.7\left(\mathrm{CH}_{2} \mathrm{OH}\right), 99.3(\mathrm{C}-5), 113.6(\mathrm{C}-4 \mathrm{a})$, 118.6 (C-6), 151.7 (C-7a), 152.51 (C-4), $159.7(C=\mathrm{O}) ; \mathrm{m} / \mathrm{z}$ (ESI+) $209[\mathrm{M}+\mathrm{H}]^{+}$; Acc Mass: 209.1038; calculated for $\mathrm{C}_{9} \mathrm{H}_{13} \mathrm{~N}_{4} \mathrm{O}_{2}$ requires 209.1039 (deviation -0.3 ppm).

\section{H. 2-Amino-5-(3-Chloropropyl)-4-Chloro-7H-Pyrrolo[2, 3-d]Pyrimidine (11)}

Compound $10(1.00 \mathrm{~g}, 4.8 \mathrm{mmol})$ was suspended in phosphoryl chloride $(7 \mathrm{ml})$ and the solution was heated at reflux overnight at $50^{\circ} \mathrm{C}$. The solution was allowed to cool and poured on to the crushed ice $(30 \mathrm{~mL})$, stir for $10 \mathrm{~min}$. and then neutralized to $\mathrm{pH} 7$ with conc. aqueous ammonia. It was left for $10 \mathrm{~min}$. in an ice-bath and then filtered. Attempt to purify the compound on the silica column chromatography $(10 \% \mathrm{MeOH} / \mathrm{DCM})$ afford the compound in pure form as pale yellow solid (200 mg, 20\%);

$R_{\mathrm{f}}(\mathrm{C}), 0.46 ; \delta_{\mathrm{H}}\left(\mathrm{d}_{6}-\mathrm{DMSO}\right) 2.05\left(2 \mathrm{H}, \mathrm{m}, \mathrm{CH}_{2} \mathrm{CH}_{2} \mathrm{Cl}\right), 2.79$ $\left(2 \mathrm{H}, \mathrm{t}, J 6.8, \mathrm{CH}_{2} \mathrm{CH}_{2} \mathrm{CH}_{2} \mathrm{Cl}\right), 3.65\left(2 \mathrm{H}, \mathrm{t}, J 6.8 \mathrm{~Hz}, \mathrm{CH}_{2} \mathrm{Cl}\right)$, $6.45\left(2 \mathrm{H}, N_{2}\right), 6.86(1 \mathrm{H}, \mathrm{s}, H-6), 11.21(1 \mathrm{H}, \mathrm{s}, N H) ; \delta_{\mathrm{C}}$ $\left(\mathrm{d}_{6}\right.$-DMSO) $22.8\left(\mathrm{CH}_{2}\right), 32.9\left(\mathrm{CH}_{2}\right), 44.9\left(\mathrm{CH}_{2} \mathrm{Cl}\right), 107.2$ (C-5), 112.3 (C-4a), 120.3 (C-6), 150.7 (C-7a), 155.1 (C-2), $159.1(C-4) ; m / z(\mathrm{ESI}+) 245[\mathrm{M}+\mathrm{H}]^{+}$; Acc Mass: 245.0355; calculated for $\mathrm{C}_{9} \mathrm{H}_{11} \mathrm{~N}_{4} \mathrm{Cl}_{2}$ requires 245.0361 (deviation -2.3 ppm).

I. 2-Amino-5-(3-Chloropropyl)-7-[2'-Deoxy-3,5-di-O-(pToluoyl)- $\beta$-D-Erythro-Pentofuranosyl]-4-Chloro-7H-Pyrr olo[2,3-d]Pyrimidine (13)

Compound $11(180 \mathrm{mg}, 740 \mu \mathrm{mol})$ was dissolved in anhydrous $\mathrm{MeCN}(20 \mathrm{~mL})$ under $\mathrm{Ar}$ at room temp. $\mathrm{NaH}(35$ 
$\mathrm{mg}, 890 \mu \mathrm{mol}, 60 \%$ in mineral oil) was added cautiously and the reaction left to stir for $1 \mathrm{~h}$, when $\alpha$-chlorosugar $(344 \mathrm{mg}$, $890 \mu \mathrm{mol})$ was added in portions over $5 \mathrm{~min}$. After that the reaction was left to stir for $3 \mathrm{~h}$, the solvent removed in vacuo, redissolved in DCM $(20 \mathrm{~mL})$ and washed with water $(50 \mathrm{~mL})$, $5 \%$ aqueous $\mathrm{HCl}(50 \mathrm{~mL})$ and brine $(50 \mathrm{~mL})$. The organic layer was then dried $\left(\mathrm{MgSO}_{4}\right)$ and evaporated to purify the residue by silica column chromatography, eluting with $2 \%$ methanol in DCM. The product 13 was isolated as pale yellow foam (400 mg, 60\%); $R_{\mathrm{f}}(\mathrm{B}), 0.35 ; \delta_{\mathrm{H}}\left(\mathrm{CDCl}_{3}\right) 1.90$ $\left(2 \mathrm{H}, \mathrm{m}, \mathrm{CH}_{2} \mathrm{CH}_{2} \mathrm{Cl}\right), 2.35\left(6 \mathrm{H}, \mathrm{s}, 2 \mathrm{x}\right.$ Tol- $\left.\mathrm{CH}_{3}\right), 2.50-2.60$ (1H, m, H2'), 2.66-2.70 (1H, m, H2"), 2.80 (2H, t, $J$ 6.8, $\left.\mathrm{CH}_{2} \mathrm{CH}_{2} \mathrm{CH}_{2} \mathrm{Cl}\right), 3.50\left(2 \mathrm{H}, \mathrm{t}, \mathrm{J} 6.8, \mathrm{CH}_{2} \mathrm{Cl}\right), 4.44-4.54(2 \mathrm{H}, \mathrm{m}$, H4' and H5'), 4.68-4.76 (1H, m, H5"), $5.10\left(2 \mathrm{H}, \mathrm{s}, \mathrm{NH}_{2}\right), 5.70$ (1H, m, H3'), 6.63 (1H, dd, J3.4, 6.8, H1'), 6.75 (1H, s, H-6), 7.21 (4H, m, meta CH-Tol), 7.91 (4H, d, J 6.8, ortho CH-Tol); $\delta_{\mathrm{C}}\left(\mathrm{CDCl}_{3}\right) 21.7 \quad\left(2 \mathrm{xTol}-\mathrm{CH}_{3}\right), 23.1 \quad\left(\mathrm{CH}_{2} \mathrm{CH}_{2} \mathrm{Cl}\right), 32.7$ $\left(\mathrm{CH}_{2} \mathrm{CH}_{2} \mathrm{CH}_{2} \mathrm{Cl}\right), 37.3\left(\mathrm{C}^{\prime}\right), 44.4\left(\mathrm{CH}_{2} \mathrm{Cl}\right), 64.2\left(\mathrm{C}^{\prime}\right), 75.1$ (C3'), 82.0 (C1'), 83.5 (C4'), 115.5 (C-4a), 119.6 (C-7a), 119.7 (C-6), 126.5 and 126.8 (2xCH $\mathrm{x}_{3}-\mathrm{C}$-Tol), 129.1, 129.2, 129.6 and 129.8 (8 orto and meta $\mathrm{CH}-\mathrm{Tol}), 144.2$ and 144.4 (2xTol- $C-\mathrm{C}=\mathrm{O}), 152.4(\mathrm{C}-5), 154.3(\mathrm{C}-4), 158.4(\mathrm{C}-2), 166.0$ and $166.2(2 \mathrm{x} C=\mathrm{O}) ; \mathrm{m} / z(\mathrm{ESI}+) 597[\mathrm{M}+\mathrm{H}]^{+}$; Acc Mass: 597.1655; calculated for $\mathrm{C}_{30} \mathrm{H}_{31} \mathrm{~N}_{4} \mathrm{O}_{5} \mathrm{Cl}_{2}$ requires 597.1672 (deviation -2.8 ppm)

\section{J. 4-Amino-2-(2'-Deoxy- $\beta$-D-Erythro-Pentofuranosyl)-6- Oxa-7,8,9-Trihydro-2,3,5-Triazabenzo[cd]Azulene (2)}

To a solution of $13(280 \mathrm{mg}, 470 \mu \mathrm{mol})$ in 1,4-dioxane (15 $\mathrm{mL}), 1 \mathrm{M}$ aqueous $\mathrm{NaOH}$ solution was added $(15 \mathrm{~mL}, 15$ $\mu \mathrm{mol})$ and the mixture was refluxed at $90^{\circ} \mathrm{C}$ for 3 days. Once the solution cooled down it was neutralised with $0.1 \mathrm{M}$ acetic acid aqueous solution $(1 \mathrm{~mL})$, then evaporated and the residue purified by silica column chromatography eluting with $10 \% \mathrm{MeOH}$ in DCM . The product 2 was obtained as a pale yellow solid (27 mg, $235 \mu \mathrm{mol}, 19 \%$ ); $\mathrm{R}_{\mathrm{f}}(\mathrm{D}), 0.50$ (fluorescent at $356 \mathrm{~nm}) ; \quad \delta_{\mathrm{H}}\left(\mathrm{d}_{6}-\mathrm{DMSO}\right) 2.08-2.12(3 \mathrm{H}, \mathrm{m}$, $\mathrm{CH}_{2} \mathrm{CH}_{2} \mathrm{O}$ and $\left.\mathrm{H} 2^{\prime}\right), 2.30-2.40$ (1H, m, H2"), 2.77 (2H, t, J 7.6 $\left.\mathrm{Hz}, \mathrm{CH}_{2} \mathrm{CH}_{2} \mathrm{CH}_{2} \mathrm{O}\right), 3.45-3.54$ (2H, m, H5' and $\left.\mathrm{H} 5^{\prime \prime}\right)$, 3.73-3.79 (1H, m, H4'), 4.25-4.29 (1H, m, H3'), 4.34 (2H, t, J 6.8, $\left.\mathrm{C}_{2} \mathrm{O}\right), 4.91\left(1 \mathrm{H}, \mathrm{t}, \mathrm{J} 6.8, \mathrm{C} 5{ }^{\prime}-\mathrm{O} \underline{\mathrm{H}}\right), 5.21(1 \mathrm{H}, \mathrm{d}, \mathrm{J} 6.8$,

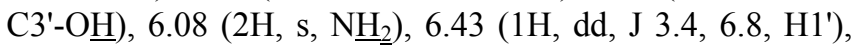
$6.92(1 \mathrm{H}, \mathrm{s}, \mathrm{H}-6) ; \delta_{\mathrm{C}}\left(\mathrm{d}_{6}\right.$-DMSO) $25.9\left(\mathrm{CH}_{2} \mathrm{CH}_{2} \mathrm{O}\right), 28.9$ $\left(\mathrm{CH}_{2} \mathrm{CH}_{2} \mathrm{CH}_{2} \mathrm{O}\right), 38.8\left(\mathrm{C}^{\prime}\right), 62.1$ (C5'), 71.1 (C3'), 71.8 $\left(\underline{\mathrm{C}} \mathrm{H}_{2} \mathrm{O}\right), 81.8\left(\mathrm{Cl}^{\prime}\right), 86.8\left(\mathrm{C}^{\prime}\right), 97.5$ (C-9a), 114.1 (C-10), 115.1 (C-1), 155.3 (C-2a), 159.7 (C-5a), 164.9 (C-4); m/z (ESI+) $329[\mathrm{M}+\mathrm{Na}]^{+}$; Acc Mass: 329.1220; calculated for $\mathrm{C}_{30} \mathrm{H}_{31} \mathrm{~N}_{4} \mathrm{O}_{5} \mathrm{Cl}_{2}$ requires 329.1226 (deviation -1.7 ppm)

\section{ACKNOWLEDGMENT}

This work was supported by studentship PTDF Nigeria and EPRSC.

\section{REFERENCES}

[1] M. J. Hickman and L. D. Samson, Molecular Cell, vol. 14, pp. 105-116, 2004,

[2] D. S. Daniels, C. D. Mol, A. S. Arvai, S. Kanugula, A. E. Pegg, and J. A. Tainer, The EMBO J, vol. 19, pp. 1719-1730, 2000.

[3] J. E. Wibley, A. E. Pegg, and P. C. Moody, Nucleic Acids Res, vol. 28, pp. 393-401, 2000.

[4] T. Lindahl, B. Demple, and P. Robins, The EMBO J, vol. 1, pp. 1359-1363, 1982.

[5] T. E. Spratt and H. de los Santos, Biochemistry, vol. 31, pp. 3688-3694, 1992.

[6] B. Demple, B. Sedgwick, P. Robins, N. Totty, M. D. Waterfield, and T. Lindahl, Proc. Natl. Acad. Sci. USA, vol. 82, pp. 2688-2692, 1985.

[7] G. P. Margison, A. Butt, S. J. Pearson, S. Wharton, A. J. Watson, A. Marriott, C. M. Caetano, J. J. Hollins, N. Rukazenkova, G. Begum, and M. F. Santibanez-Koref, DNA Repair, vol. 6, pp. 1222-1228, 2007.

[8] A. E. Pegg, M. Boosalis, L. Samson, R. C. Moschel, T. L. Byers, K. Swenn, and M. E. Dolan, Biochemistry, vol. 32, pp. 11998-12006, 1993.

[9] A. E. Pegg, M. E. Dolan, and R. C. Moschel, Prog. Nucl. Res .Mol. Biol., vol. 51, pp. 167-223, 1995.

[10] I. Teo, B. Sedgwick, B. Demple, B. Li, and T. Lindahl, The EMBO J, vol. 3, pp. 2151-2157, 1984.

[11] D. M. Noll and N. D. Clarke, Nucleic Acids Res, vol. 29, pp. 4025-4034, 2001.

[12] M. Bartra, P. Romea, F. Urpí, and J. Vilarrasa, Tetrahedron, vol. 46, pp. 587-594, 1990.

[13] D. M. Williams, D. Y. Yakovlev, and D. M. Brown, J. Chem. Soc., Perkin Trans. 1, pp. 1171-1178, 1997.

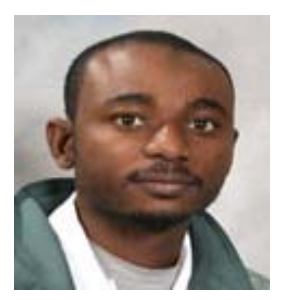

Kabir Abdu was born on the $4^{\text {th }}$ June, 1974. He had PhD Organic Chemistry (2011, University of Sheffield, UK), MSc Organic Chemistry and BSc Chemistry (2004 and 1998 respectively both at Bayero University Kano Nigeria).

$\mathrm{He}$ roused from the rank of a graduate assistant in 2000 to a rank of assistant professor in 2012 at Bayero Universitry Kano Nigeria. His major research interest is on the studies of the synthesis of some modified nucleosides analogue of methyl-2'-deoxyguanosine as well as their incorporation into synthetic oligomers for AGT inactivation.

Dr. Abdu has the following membership. Member American chemical society (MACS); Associate member royal society of chemistry, UK (AMRSC); member society for chemical industries. UK (MSCl); member institute of chartered chemist of Nigeria (MICCON) and member chemical society of Nigeria (MSCN). He received a cash award for the best presentation in the $4^{\text {th }}$ nucleic acid forum, (NAF) in 2010 at the University of Liverpool, UK. He also received Michael Collin's prize for the best graduating student in chemistry (1998) at Bayero University Kano Nigeria. 